\begin{tabular}{|c|c|c|}
\hline \multirow{2}{*}{ N/ } & $\begin{array}{l}\text { Науковий вісник НЛТУ України } \\
\text { Scientific Bulletin of UNFU }\end{array}$ & $\begin{array}{l}\text { ISSN 1994-7836 (print) } \\
\text { ISSN 2519-2477 (online) }\end{array}$ \\
\hline & http://nv.nltu.edu.ua & \\
\hline Нᄉिษ & https://doi.org/10.15421/40280127 & $@ \bowtie$ Correspondence author \\
\hline & $\begin{array}{l}\text { Article received } 24.01 .2018 \mathrm{p} . \\
\text { Article accepted } 28.02 .2018 \mathrm{p} .\end{array}$ & $\begin{array}{r}\text { T. T. Moskaluk } \\
\text { Taras.moskalyk@gmail.com }\end{array}$ \\
\hline & УДк 801.675 .2 & \\
\hline
\end{tabular}

Т. Т. Москалюк, Т. Р. Цимбаляк, А. Ю. Берко

Національний університет "Львівська політехніка", м. Львів, Україна

\title{
ПОРІВНЯННЯ СRМ-СИСТЕМ
}

Розглянуто сучасний ринок CRM-систем країн СНГ, обрано кілька найпопулярніших систем і подано характеристику кожної з них. Порівняння шести CRM-систем за шістнадцятьма ознаками подано у вигляді таблиці. Використовуючи інформацію з цієї таблиці і оперуючи запропонованою системою порівняння, будь-хто зможе без проблем оцінити і вибрати будьяку іншу CRM. В огляді розглянуто такі системи: Megaplan CRM, bpm'online Sales, Bitrix 24 CRM, Amo CRM, 1C CRM, Mango CRM. Надано рекомендації щодо опрацювання таблиці. Оцінювання проведено за 4-бальною шкалою, деякі функції мають не числовий, а текстовий формат порівняння. Обчислювати загальну кількість балів для кожної системи і вибирати ії на такій підставі не рекомендовано, оскільки у кожної системи є свої сильні і слабкі позиції, а вибирати систему потрібно відповідно до головних вимог і наявності необхідного функціоналу. Виявлено слабкі і сильні позиції кожної з порівнюваних СРМ, подано в детальному описі під даними таблиці. З'ясовано, що дані системи можуть підійти для малих і середніх компаній. Під час вибору системи рекомендовано оцінити основні вимоги компанії до CRM і з'ясувати, в якої із систем необхідні функції реалізовані найкраще. На нашу думку, це дослідження допоможе недосвідченим молодим компаніям обрати CRM-систему, яка найкраще підходить вимогам їхнього бізнесу. Також для кожної з поданих у роботі систем взаємодії 3 клієнтами оцінено вплив їх впровадження на конкретний бізнес для вирішення типових повсякденних завдань підприємства.

Ключові слова: ринок СНГ; Megaplan CRM; Bitrix 24 CRM; Amo CRM; 1C CRM; Mango CRM.

Вступ. Ринок CRM-систем стрімко розширюється, i користувачам стає дедалі складніше об'єктивно оцінити ту чи іншу систему і прийняти рішення, на якій з них зупинити свій вибір. До того ж не завжди є змога самостійно протестувати різні системи. І в цьому разі не обійтися без професійної допомоги.

Нагадаємо, що під CRM (англ. Customer Relationship Management) розуміють поняття, що охоплює концепції, котрі використовуються компаніями для управління взаємовідносинами зі споживачами, включаючи збір, зберігання й аналіз інформації про споживачів, постачальників, партнерів та інформації про взаємовідносини 3 ними. У цій роботі, головна мета якої - допомогти користувачам у виборі CRM, наведено зведену порівняльну таблицю таких систем, які $є$ найпопулярнішими на ринку країн СНГ.

Матеріали та методи дослідження. У таблиці порівнюють 6 CRM-систем за 16 ознаками. Виявлено, що орієнтуючись на інформацію цієї роботи й оперуючи запропонованою системою порівняння, можна без проблем оцінити і вибрати будь-яку іншу CRM (Camponovo et al., 2005).

Отже, в огляді буде розглянуто такі системи: Megaplan CRM, bpm'online Sales, Bitrix 24 CRM, Amo CRM, 1C CRM, Mango CRM (Close \& Eisenfeld, 2001).

Відомо, що для бізнесу країн СНГ ці системи мають низку переваг:
- дані системи враховують специфіку бізнесу, вони здебільшого інтегровані $з$ іншими рішеннями, орієнтованими на вітчизняний ринок (1c, SIP-телефонія, конструктори лендінг-сторінок і т. ін.);

- фахівця для підтримки простіше знайти, ніж для іноземної системи;

- дані CRM призначені передусім для малого і середнього бізнесу і для вирішення загального кола завдань, тобто дані CRM не специфічні за своїми функціями.

У верхньому рядку таблиці наведено назви CRMсистем, а в лівій колонці - назви функцій. На перетині подано оцінку за 4-бальною шкалою, де: 0 - функція відсутня в системі; 1 - функція присутня, але через складність або навпаки примітивність, нею неможливо користуватися; 2 - функцією можна користуватись, але необхідні зусилля з боку програміста і / або консультанта; 3 - функцією можна скористатися 3 коробки в разі певної підготовки (прочитавши інструкцію). Деякі функції мають не числовий, а текстовий формат порівняння (Budiardjo, Perdana \& Franshisca, 2012).

Обчислювати загальну кількість балів для кожної системи і вибирати іiї на такій підставі не потрібно. У кожної системи є свої сильні і слабкі позиції, і вибирати систему рекомендовано відповідно до ваших головних вимог і наявності необхідного функціоналу.

Результати дослідження та їх обговорення. У таблиці не розглянуто функції експорту та імпорту, оскіль-

Інформація про авторів:

Москалюк Тарас Тарасович, аспірант кафедри інформаційних систем та мереж. Email: Taras.moskalyk@gmail.com

Цимбаляк Тетяна Ростиславівна, студент кафедри інформаційних систем та мереж. Email: Tanya.tsymbaliak@gmail.com Берко Андрій Юліанович, д-р техн. наук, професор кафедри інформаційних систем та мереж. Email: BerkoAndriy@i.ua Цитування за ДСтУ: Москалюк Т. Т., Цимбаляк Т. Р., Берко А. Ю. Порівняння СRМ-систем. Науковий вісник НЛТУ України. 2018, т. 28, № 1. С. 136-139.

Citation APA: Moskaluk, T. T., Tsimbalyak, T. R., \& Berko, A. Yu. (2018). Comparison of CRM-Systems. Scientific Bulletin of UNFU, 28(1), 136-139. https://doi.org/10.15421/40280127 
ки всі CRM-системи з цим справляються на належному рівні, і ці операції проводяться не так часто. Однак, якщо вам постійно доводиться вивантажувати і завантажувати дані, рекомендовано використовувати АРI.

Отже, перейдемо до самої таблиці.

Таблиця. Порівняння СRM-систем

\begin{tabular}{|c|c|c|c|c|c|c|}
\hline $\begin{array}{c}\text { Функці- } \\
\text { онал/CRM- } \\
\text { системи } \\
\end{array}$ & $\begin{array}{l}\text { Megap- } \\
\text { lan } \\
\text { CRM }\end{array}$ & $\begin{array}{l}\text { bpm } \\
\text { online } \\
\text { Sales }\end{array}$ & $\begin{array}{c}\text { Bitrix } \\
24 \text { CRM }\end{array}$ & $\begin{array}{l}\text { AMO } \\
\text { CRM }\end{array}$ & $\begin{array}{c}1 \mathrm{C} \\
\mathrm{CRM}\end{array}$ & $\begin{array}{l}\text { Man- } \\
\text { go } \\
\text { CRM } \\
\end{array}$ \\
\hline $\begin{array}{l}\text { Робота із } \\
\text { продажами }\end{array}$ & 3 & 3 & 2 & 1 & 1 & 2 \\
\hline Телефонія & 2 & 1 & 1 & 1 & 2 & 3 \\
\hline Бізнес-процеси & 0 & 3 & 3 & 0 & 1 & 2 \\
\hline Задачі & 3 & 2 & 3 & 1 & 3 & 1 \\
\hline $\begin{array}{l}\text { Email-po3- } \\
\text { силка }\end{array}$ & 1 & 2 & 1 & 1 & 1 & 0 \\
\hline Email-клієнт & 1 & 1 & 1 & 1 & 3 & 1 \\
\hline $\begin{array}{l}\text { Налаштуван- } \\
\text { ня інтерфейсу }\end{array}$ & 1 & 3 & 1 & 1 & 1 & 0 \\
\hline $\begin{array}{l}\text { Права досту- } \\
\text { пу }\end{array}$ & 2 & 2 & 1 & 1 & 2 & 1 \\
\hline Звітність & 1 & 2 & 1 & 1 & 3 & 1 \\
\hline Веб-форми & 0 & 1 & 2 & 3 & 0 & 0 \\
\hline API & 2 & 1 & 2 & 3 & 3 & 0 \\
\hline $\begin{array}{l}\text { Можливість } \\
\text { доопрацювання }\end{array}$ & 0 & 3 & 1 & 1 & 3 & 0 \\
\hline $\begin{array}{l}\text { Розподіл на лі- } \\
\text { ди і контакти }\end{array}$ & $\mathrm{Hi}$ & Так & Так & $\mathrm{Hi}$ & $\mathrm{Hi}$ & $\mathrm{Hi}$ \\
\hline $\begin{array}{l}\text { Варіант пос- } \\
\text { тавки }\end{array}$ & $\begin{array}{l}\text { SAAS } \backslash \\
\text { Stand } \\
\text { Alone }\end{array}$ & SAAS & $\begin{array}{l}\text { SAAS } \backslash \\
\text { Stand } \\
\text { Alone }\end{array}$ & SAAS & $\begin{array}{l}\text { SAAS } \\
\text { Stand } \\
\text { Alone } \\
\end{array}$ & SAA \\
\hline $\begin{array}{l}\text { Якість доку- } \\
\text { ментації }\end{array}$ & $\begin{array}{l}\text { Висо- } \\
\text { кий }\end{array}$ & $\begin{array}{l}\text { Висо- } \\
\text { кий }\end{array}$ & $\begin{array}{c}\text { Серед- } \\
\text { ній }\end{array}$ & $\begin{array}{c}\text { Серед- } \\
\text { ній }\end{array}$ & $\begin{array}{c}\text { Низь- } \\
\text { кий }\end{array}$ & \begin{tabular}{|c|} 
Се- \\
редня
\end{tabular} \\
\hline $\begin{array}{l}\text { Рівень важ- } \\
\text { кості системи }\end{array}$ & $\begin{array}{l}\text { Низь- } \\
\text { кий }\end{array}$ & $\begin{array}{c}\text { Висо- } \\
\text { кий }\end{array}$ & $\begin{array}{c}\text { Висо- } \\
\text { кий }\end{array}$ & $\begin{array}{l}\text { Низь- } \\
\text { кий }\end{array}$ & $\begin{array}{c}\text { Висо- } \\
\text { кий }\end{array}$ & $\begin{array}{r}\text { Низь- } \\
\text { кий }\end{array}$ \\
\hline
\end{tabular}

Обговорення отриманих результатів дослідження

Система Bitrix 24. У системі є поля, що налаштовують "Угоди" і "Контакти", досить великий вибір можливостей $з$ налаштування задач, присутній календар їх відображення.

Працює з 2009 р., орієнтована на російський ринок, швидко і впевнено розвивається. Бітрікс 24 - багатофункціональна CRM-система, яка спрощує роботу не тільки 3 клієнтами, але і допомагає вести процеси всередині компанії. Пропонують як хмарні рішення, так і "коробку". Після реєстрації бачимо три колонки, де зліва буде основне меню, посередині - стрічка з подіями, а праворуч - повідомлення (Band, 2008).

\section{Плюси:}

• найбільш багатофункціональна;

• робота 3 документами (*.doc, *.pdf, *.xls i т.д.) всередині сервісу;

- виглядає як соцмережа - звично;

- $є$ відеочати;

- можна створити безкоштовно робочу пошту;

- елементи Гейміфікації;

- інтеграція з соцмережами, google-календарем й іншими сервісами;

- інтеграція з 1C-бітрікс й іншими відомими CRM-системами;

- $є$ телефонія;

- $є$ безкоштовний тариф. Мінуси:

• найголовніший плюс - це і мінус, занадто багато функцій, довго і важко розбиратися;

- візуальне сміття - проблеми інтерфейсу;

- незрозумілий і візуально неприємний таск-менеджер;

- слабка проробка CRM: немає договорів, контрактів, шаблонів документів.

Унікальні фішки:
Багатофункиіональний. Бітрікс24 по праву вважають найбільш багатофункціональною CRM-системою. Повноцінна адмінка компанії, яка враховує і роботу із кліснтами.

Сочіальна мережа. Розробники постаралися, щоб система виглядала як соціальна мережа. Всередині співробітники можуть писати пости, публікувати фотографiï, збирати лайки і коментарі від колег. Це звично і піднімає настрій команди.

Мотивація $і$ емоиіï. Сервіс розроблений з елементами Гейміфікації. Наприклад, для додаткової мотивації в Бітрікс24 придумали "бейджі". Керівник дарує бейджі тим співробітникам, які відзначилися на роботі.

Проиеси. Велика увага приділяється процесам всередині компанії. Керівник бачить, над якими завданнями в цей момент працюють співробітники і коли вони їх вирішують. Можна зібрати статистику за задачами в кінці місяця і оформити все це у вигляді зручної інфографіки.

Телефонія. Мабуть, найкраща сторона Бітрікс24 - телефонія. Система працює з багатьма великими компаніями. Є можливість створювати віртуальні номери та АТС.

Bapmicmь. Оскільки Бітрікс24 пропонує "хмару" i "коробку", то для наочності краще розділити тарифи так.

Онлайн-тарифи. Компанія купує хмарне сховище. Підійде для дрібних і середніх компаній. Якщо говорити про середні цифри, то за місяць доведеться віддати від 500 до 5500 грн.

"Проект" - безкоштовний тариф. Незважаючи на це, передбачає і CRM. Дається хмарне сховище до 5 Гб для кожного співробітника (користувача). Можна зареєструвати до 12 бізнес-користувачів, які мають перевагу перед іншими користувачами - для них відкрито більше функцій. Немає мульти-воронок, обліку робочого часу, глибокого перегляду історії листів, розсилки за базою клієнтів, журналу доступу співробітників до CRM та інших корисних можливостей.

"Проект +" - коштуе (15 грн/міс. зі співробітника). Пропонує те ж саме, що і в "Проект", тільки тут більше бізнес-можливостей і простору на віртуальному диску 24 Гб для кожного. Також можна підключити до 24 бізнес-користувачів.

"Команда" - необмежена кількість бізнес-користувачів, 100 Гб простору, коштує 68 грн/міс. 3 кожного. Більше можливостей, ніж у попередньому тарифі, але не всі - немає аудиту, відновлення бекапу, звіту за робочим часом і ще пари-трійки функцій.

"Компанія" - необмежена кількість бізнес-користувачів і простору в віртуальному диску (135 грн/міс.). У тариф включено всі можливості.

Офлайн-тарифи. Орієнтовані для великих компаній, корпорацій, холдингу, які хочуть "коробку". Якщо говорити про середню ціну, то в межах 110 тис. грн, а потім підтримка в робочому стані за тарифами "Корпоративний портал" i "Холдинг". Перший коштує 2700 грн, а другий - 6600. Відмінність першого від другого, окрім ціни, ще в тому, що для другого дається більше місця для бекапу - 50 Гб + (для першого 20 Гб). Включено всі можливості системи.

Система Mango. Для малого та середнього бізнесу Mango має кілька переваг: немає додаткової плати за використання, і тому система створена насамперед для роботи 3 клієнтською базою інтернет-магазинів, має простий і не перевантажений інтерфейс, але програма має не великий набір функціоналу, не вистачає можливості аналітики і маркетингового блоку. 
Система AmoCRM. На ринку вже 9 років. Якщо Бітрікс24 багатофункціональний i складний, то amoCRM - повна протилежність: тільки "хмара", тільки CRM і простота. $€$ зрозуміла воронка продажів і телефонія. B "AmoCRM" є змога відзначати угоди і контакти тегами (Greenberg, 2010). Досить великий інтерфейс і величезний функціонал є одночасно і мінусом, і плюсом (Budiardjo \& Perdana, 2008).

Плюси: простий, красивий і зрозумілий інтерфейс; пророблена CRM; є телефонія; інтеграція $з$ великою кількістю сервісів, більшість російські.

Мінуси: малофункціональний; тільки хмарне рішення; купуєте мінімум на півроку.

\section{Унікальні фішки системи.}

Iнтеграиія. Дані можна перенести з відомих сервісів, можна з таблиць. $€$ інтеграція з календарями, поштою, соцмережами. Добре інтегрується з усім російським.

Угоди. У сервісі велику увагу приділяють операціям. У кожного покупця своя картка. У цій картці знаходиться вся інформація про нього: відповідальний менеджер, контакти, який статус угоди.

Воронка продажів. Чудово реалізовано, у цій вкладці екран розділений на етапи (колонки), які показують те, як угода проходить. Зліва - початок, праворуч, в самому кінці - покупка. Картки, природно, можна перетягувати $з$ однієї колонки в іншу. Ведеться статистика (оформляється в наочну інфографіку) і $є$ адекватний пошук за операціями.

Інтерфейс приємний $i$ зрозумілий. $Є$ мобільні додатки для iOS i Android, які мають такі корисні функції, як сканер візиток, який може автоматично створити картку клієнта і так далі.

Bapmicmь системи. Немає безкоштовного тарифу, але зате $\epsilon$ двотижневий пробний період, який показує всі переваги сервісу. А що стосується тарифів, вони такі.

"Базовий" - коштує 250 грн/міс. за користувача. Підходить для компаній 3 невеликим обсягом продажів. Можна створювати угоди, додавати контакти. $€$ інтеграція з "Google Universal Analytics". С і об'єднання дублікатів - знаходить картки 3 одним і цим самим клієнтом і об'єднує їх. Включена і робота 3 лійкою.

"Розширений" - коштує 400 грн/міс. 3 користувача. Як вони самі згадують на своєму сайті, для компаній, які хочуть оптимізувати конверсію. $€$ ті самі функції, що і в базовому, плюс KPI, доопрацювання робочого столу і план продажів для менеджерів.

"Професійний" - коштує 750 грн/міс. 3 користувача. Усі можливості сервісу, зокрема, робота з лідами і періодичний бекап даних. Архів даних можна отримувати i на пошту, все налаштовується.

Усі ці тарифи оплачуються мінімум за півроку. Інформацію про сховище для файлів не знайшли. Можна тільки підключити віджет Дропбокса.

$\epsilon$ ще й річні пакети.

"Мікро-бізнес" - коштує 2500 грн/рік. Для новачків, які нещодавно відкрили свій бізнес і вже доводиться працювати із клієнтами.

"Старт-ап" - коштує 7500 грн/рік. Для молодих команд, де немає керівника і немає великого виторгу, але працювати із клієнтами треба.

Система Megaplan. Ці вже 10 років працюють, в основному, на ринку СНГ. Пропонують зручний сервіс для ведення процесів, завдань і роботи із клієнтами. Можна сказати, що Мегаплан такий самий, як і Бітрікс24, але в менших масштабах і з великою увагою до комфорту користувача, бухгалтерії та документації. Система нагадуе про податки, полегшує роботу бухгалтера, менеджерів. Добре підійде керівникам, які хочуть все контролювати: бачимо всю статистику щодо виконання завдань, з продажу (доходи, просування по воронці).

y "Megaplan" користувачеві доступна велика частина налаштування параметрів, система відстежує та дає змогу організувати процес за допомогою шаблонів документів, гнучка система звітності. Можна використовувати систему безкоштовно, але 3 обмеженням числа користувачів до трьох.

Плюси: безлімітне хмарне сховище; велика увага до документації (шаблони, автоматизація); виявляє ледарів; $є$ зручний калькулятор для тарифів; гідна інтеграція 3 іншими сервісами; опитування всередині загального чату; встановлюють "коробку".

Мінуси: складний інтерфейс; не можна будувати складні звіти: облік складу, перехресний облік.

Унікальні фішки системи.

Калькулятор помітно полегшує підрахунок вартості того чи іншого тарифу. Індивідуальний підхід, тобто в калькуляторі вам потрібно вибрати тариф, кількість співробітників, термін, на який хочете користуватися і все. Внизу покаже, скільки це буде коштувати в підсумку. Досі не розумію, чому конкуренти не додумалися до цього.

Дзвінок прямо з сайту. У кутку є посилання, клікнувши на яку можна зателефонувати в будні дні i зв'язатися 3 довідковою службою. Знову ж таки, зручно.

Шаблони документів. Творці і тут подбали про комфорт користувача. $\mathcal{C}$ готові шаблони документів. $\mathcal{C}$ автоматична підготовка документів по звітах. Рахунки, підрахунок податків, збір статистики з менеджерів.

Система подвоєння продажів - серія відеокурсів 3 навчання продажам. Допоможе новачкам, лунає безкоштовно для користувачів.

Bapmicmь системи. Так само, як у інших, є двотижневий тріал. Є як "хмара", так і "коробка".

"Хмара", "Спільна робота" і "Спільна робота +" - тарифи тільки для процесів і завдань, без CRM, інтеграції 3 поштою, 1C, Октелл і телефонії. Перший коштує 165 грн/міс. 3 користувача, другий - 190. Відрізняються тільки тим, що в другому трохи більше бізнес-функцій: робота 3 документами, опитуваннями, оцінка завдань i проектів.

"CRM: робота 3 клієнтами" і "CRM: робота 3 клієнтами +" - робота не тільки всередині компанії, але і 3 клієнтами. Перший коштує 275 грн/міс. 3 користувача, другий - 320. Відмінність між цими тарифами така сама як і в перших двох тарифах.

"Коробка". Тут тарифи і їх можливості точно такі самі, як і в хмарному вирішенні. Відмінність тільки в ціні і в тому, що це коробкове рішення. Прийдуть, встановлять ПО на ваш сервер і будуть підлаштовувати під вас.

"Спільна робота" і "Спільна робота +"- $2650 \mathrm{i}$ 3100 грн $з$ користувача відповідно.

"CRM: робота 3 клієнтами" і "CRM: робота 3 клієнтами +" - 4750 і 5225 грн. Пишуть, що до 10 користувачів можуть користуватися Мегаплані безкоштовно.

$€$ й "Мегаплан 2", який з цінами і сховищем виглядає так:

- "Хмара" - 175 грн 3 користувача на місяць (мінімум 5 користувачів (ліцензій)). $€$ знижки і ціни для юридичних осіб. 100 Гб простору. 
- "Коробка" - 2855 грн 3 людини в компанії. Сховище залежить від вашого сервера. 1000 смс для повідомлень (Раyne, 2005).

Система BPM'online. Ця система вже не перший рік займає перші рядки рейтингів CRM. Відмінні аналітичні можливості системи: можливість простежити шлях від першого звернення клієнта до здійснення покупки, продумана система електронного документообігу, інтеграція з фінансовими програмами. До недоліків можна віднести високу ціну, відсутність безкоштовних оновлень. Зважаючи на це ця CRM все-таки більше підходить для великого бізнесу (Park \& Kim, 2003).

Висновок. Підготувавши цю таблицю, виявлено, наскільки представлені системи відрізняються за своїми характеристиками.

Ці системи цілком можуть підійти для малих і ceредніх компаній. У кожної з представлених систем $\epsilon$ свої сильні і слабкі позиції. Під час вибору системи рекомендовано оцінити основні вимоги компанії до CRM і подивитися, в якої зі систем необхідні функції реалізовані найкраще, а якими функціями СРМ можна пожертвувати і вони не важливі для функціонування бізнесу.

\section{Перелік використаних джерел}

Band, W. (2008). Overview: Customer Relationship Management 2008. Executive Report, Forrester Research. Retrieved from: https://experiencematters.blog/2008/12/15/forrester $\% E 2 \% 80 \% 99 \mathrm{~s}-$ 2008-customer-experience-rankings/

Budiardjo, E. K., \& Perdana, W. (2008). FrontCRM: A Framework based on Theory of CRM, Penerapannya pada Toko Buku berskala UKM. In: Prosiding Seminar Nasional Aplikasi Teknologi Informasi 2008 (SNATI 2008), (pp. A-149 - A-158). Yogyakarta, Indonesia.

Budiardjo, E. K., Perdana, W., \& Franshisca, F. (2012). The Ontology Model of DrontCRM Framework. In: $20124^{\text {th }}$ International Conference on Graphic and Image Processing Proceeding, (pp. 316320). SPIE, Singapore.

Camponovo, G., Pigneur, Y., Rangone, A., \& Renga, F. (2005). Mobile Customer Relationship Management: An Explorative Investigation of the Italian Consumer Market. In: Proceedings of the 4th International Conference on Mobile Business, (pp. 42-48). Sydney, Australia.

Close, W. S., \& Eisenfeld, B. (2001). CRM at Work: Eight Characteristics of CRM Winners. Project Report. Gartner Research. Retrieved from: http://www.gartner.com/resources/98800/98877/crm at work eight characteri $98877 \mathrm{pdf}$

Greenberg, P. (2010). Customer Relationship Management at the speed of light: social CRM strategies, tools, and techniques for engaging your customers, (4th ed.). McGraw-Hill, USA. 320 p.

Park, C. H., \& Kim, Y. G. (2003). A Framework of Dynamic CRM: Linking Marketing with Information Strategy. Business Process Management Journal, 9(5), 652-671. https://doi.org/10.1108/14637150310496749

Payne, A. (2005). Handbook of CRM, Achieving Excellence in Customer Management. Elsevier, Burlington, MA. 260 p.

Т. Т. Москалюк, Т. Р. Цимбаляк, А. Ю. Берко

Национальный университет "Львовская политехника", г. Львов, Украина

Рассмотрен современный рынок CRM-систем стран СНГ, избрано несколько самых популярных систем и дана характеристика каждой из них. Сравнение шести CRM-систем по шестнадцати признакам представлено в виде таблицы. Используя информацию из данной таблицы и оперируя предложенной системой сравнения, любой сможет без проблем оценить и выбрать любую другую CRM. В обзоре рассмотрены следующие системы: Megaplan CRM, bpm'online Sales, Bitrix 24 CRM, Amo CRM, 1C CRM, Mango CRM. Предоставлены рекомендации к чтению таблицы. Оценку проведено по 4-балльной шкале, некоторые функции имеют не числовой, а текстовый формат сравнения. Вычислять общее количество баллов для каждой системы и выбирать ее таким образом не рекомендовано, поскольку у каждой системы есть свои сильные и слабые стороны, а выбирать систему нужно в соответствии с вашими главными требованиям и наличием необходимого функционала. Выявлены слабые и сильные стороны каждой из сравниваемых СРМ и предоставлены в подробном описании под данными таблицы. Выяснено, что данные системы могут подойти для малых и средних компаний. При выборе системы рекомендовано оценить основные требования компании к CRM и посмотреть, в какой из систем необходимые функции реализованы лучше. Также оценено влияние внедрения представленных в исследовании систем взаимодействия с клиентами на конкретный бизнес для решения типовых повседневных бизнес-задач предприятия.

Ключевые слова: рынок СНГ; Megaplan CRM; Bitrix 24 CRM; Amo CRM; 1C CRM; Mango CRM.

\section{T. T. Moskaluk, T. R. Tsimbalyak, A. Yu. Berko Lviv Polytechnic National University, Lviv, Ukraine}

\section{COMPARISON OF CRM-SYSTEMS}

The authors have examined the current market of CRM systems of the CIS countries, selected some of the most popular systems and given the characteristics of each of them. The comparison of six CRM-systems by sixteen signs is presented as a table. Using information from this table and operating the proposed comparison system, anyone can easily evaluate and choose any other CRM. The review will consider the following systems: Megaplan CRM, bpm'online Sales, Bitrix 24 CRM, Amo CRM, 1C CRM, Mango CRM. The recommendations for the analysing of the table were provided. The score is based on the 4-point scale; some of the functions have non-numeric, but the text format of the comparison. It is not recommended to calculate the total number of points for each system and to choose it after this calculation, because each system has its own strengths and weaknesses, and it is necessary to choose the system according to your main requirements and the availability of the necessary functionality. The weaknesses and strengths of each of the compared CRMs were found and presented in a detailed description below the table. It is explained that these systems can be suitable for small and medium-sized companies. During the selection it is recommended to evaluate the main requirements to the CRM system and analyze where these functions are best implemented. For example, there are customizable fields in the Bitrix24 system - "Agreements" and "Contacts", a fairly large selection of options for setting up tasks, a calendar to display them, a corporate portal with cloud storage and video chats. BPMonline, in its turn, occupies the first lines of CRM ratings, has excellent analytical capabilities of the system: the ability to trace the path from the first client appeal to purchase, a well-thought-out electronic document management system, integration with financial programs, but unlike Bitrix 24 , it does not have a corporate portal and has a fairly high subscription price. Therefore, the choice of the CPM for the enterprise should be guided primarily by the needs of the enterprise. The impact of the implementation on a particular business was assessed for each of the submitted systems.

Keywords: CIS market; Megaplan CRM; Bitrix 24 CRM; Amo CRM; 1C CRM; Mango CRM. 